\title{
Decision phase regulation of streptomycin production in Streptomyces griseus
}

\author{
Thomas Neumann, Wolfgang Piepersberg and Jürgen Distler \\ Author for correspondence: Jürgen Distler. Tel: +49202439 2798. Fax: +492024392698. \\ e-mail: distler@wrcs2.urz.uni-wuppertal.de
}

Institut fur Chemische Mikrobiologie, Bergische Universităt GH Wuppertal, Gauss-Str. 20, 42109 Wuppertal, Germany

\begin{abstract}
The streptomycin (Sm) producer, Streptomyces griseus N2-3-11, shows medium-independent biphasic kinetics of the vegetative or exponential growth phase (EGP), reflecting an innate clock-like behaviour of growth and differentiation. The $S$. griseus growth and development cycle has the following characteristics: (1) after the developmental cycle commences, it cannot be influenced by environmental conditions; (2) the first EGP (decision phase) and its duration seem to be genetically determined, and it is also exhibited in pleiotropic mutants deficient in differentiation and antibiotic production; (3) during this early phase of growth, the decision to produce Sm is established and the fixation of later production and differentiation can only be influenced by effector molecules, e.g. A-factor, during this period; (4) after the onset of the second EGP, the commitment to Sm production cannot be reversed by dilution into fresh medium, nor by effector molecules; (5) the length of time of this effector-insensitive growth phase (second EGP or execution phase) can be extended by dilution into fresh medium; (6) the differentiation cycle of $S$. griseus is completed on entering stationary phase. The cells of $S$. griseus then return to a decision-making stage and recover sensitivity to effector molecules. Evidence that this type of phasing is valid for the growth and developmental cycles of all streptomycetes is discussed.
\end{abstract}

Keywords: Streptomyces griseus, streptomycin, biosynthesis, regulation, A-factor

\section{INTRODUCTION}

Due to their great importance in the production of a large variety of enzymes and low-molecular-mass secondary metabolites, members of the genus Streptomyces are the best-studied group of the Gram-positive myceliumforming Actinomycetales. Knowledge of the biosynthetic pathways of secondary metabolites has improved at the biochemical and genetic levels during recent years (for reviews see Hopwood \& Sherman, 1990; Piepersberg, 1995). It is both of biological interest and of great importance for the production of secondary metabolites by fermentation to understand the molecular events involved in (1) regulating these complex biosynthetic pathways, (2) inducing secondary metabolism and differentiation and (3) linking primary and secondary pathways.

Streptomycetes undergo a complex life-cycle on solid media, including spore germination, vegetative growth of

Abbreviations: 2-D, two-dimensional; EGP, exponential growth phase; SGP, stationary growth phase; $t_{d}$, doubling time. substrate mycelium, formation of aerial mycelia and sporulation. In liquid medium the growth of Streptomyces is similar to that of non-filamentous bacteria in showing the three classical growth phases: lag, exponential and stationary. This picture of the growth of Streptomyces in liquid medium was first challenged by Thompson and coworkers (Holt et al., 1992). Streptomyces bygroscopicus, which produces the herbicide bialaphos, exhibited a biphasic exponential growth phase (EGP) with a reproducible deceleration of growth between 14 and $16 \mathrm{~h}$ following inoculation. Interestingly, this pause in growth was associated with a peak level of ppGpp and the induction of expression of the bialaphos biosynthetic genes. Maximum bialaphos synthesis was only attained in stationary phase about $8 \mathrm{~h}$ later.

The physiology, enzymology, genetics and regulation of the synthesis of streptomycin ( $\mathrm{Sm}$ ) by Streptomyces griseus has been intensively studied (reviewed by Piepersberg, 1995). The synthesis of $\mathrm{Sm}$ is regulated by a complicated network including pleiotropic regulators (Horinouchi \& Beppu, 1992) and the regulator protein, StrR, encoded by a gene of the biosynthetic gene cluster for Sm (Retzlaff $e t$ 
al., 1993; Retzlaff \& Distler, 1995). In addition to these regulators, a hormone-like autoregulator, A-factor, controls the production of $\mathrm{Sm}$ in $S$. griseus at the level of gene expression via a still-unknown mechanism (Horinouchi \& Beppu, 1994). The induction of Sm synthesis had commonly been described as a response to nutrient limitation in the stationary growth phase (SGP), probably mediated by ppGpp (Martin, 1989; Demain, 1989; Ochi, 1987a, b). However, Ensign (1988) showed that the sporulation of S. griseus NRRL 2682 in liquid medium is not caused by nutrient deprivation, but is dependent on a developmental cycle based on a clock-like mechanism.

In this paper, we demonstrate that the physiological decision of $S$. griseus cells to produce or not to produce $\mathrm{Sm}$, is made very early in the growth phase. This 'decision phase' of Sm synthesis is part of a periodic developmental cycle which occurs independently of changes in the environment. After the decision-making point has been passed, there follows a factor-independent phase, called the execution phase, which can be influenced in its extension by physiological parameters. Cells are returned to a decision-making state in the early stationary phase.

\section{METHODS}

Strains and culture media. The strains used in this study are given in Table 1. The standard minimal medium (MM) contained $50 \mathrm{mM}$ glucose, $60 \mathrm{mM}$, L-asparagine, $15 \mathrm{mM}$ $\left(\mathrm{NH}_{4}\right)_{2} \mathrm{SO}_{4}, 20 \mathrm{mM}$ Tris/ $\mathrm{HCl}, 17 \mathrm{mM} \mathrm{NaCl}, 3 \mathrm{mM} \mathrm{K}_{2} \mathrm{SO}_{4}$, $2.5 \mathrm{mM} \mathrm{KH}_{2} \mathrm{PO}_{4}, 0.8 \mathrm{mM} \mathrm{MgSO}, 0.7 \mathrm{mM} \mathrm{CaCl}_{2}$ and $10 \mathrm{ml}$ trace elements solution. The $\mathrm{pH}$ of the medium was adjusted to 7.2. The 100-fold-concentrated stock solution of trace elements contained $5 \mathrm{mM}$ each of $\mathrm{FeSO}_{4}, \mathrm{ZnCl}_{2}, \mathrm{MnCl}_{2}, \mathrm{CoCl}_{2}$ and $\mathrm{NH}_{4} \mathrm{Mo}_{7} \mathrm{O}_{24}$. L-Asparagine $(100 \mathrm{ml} 0.6 \mathrm{M}, \mathrm{pH} 7 \cdot 2)$ and potassium phosphate $(10 \mathrm{ml} 0.25 \mathrm{M}, \mathrm{pH} 7 \cdot 2)$ were autoclaved separately and added aseptically to the other ingredients dissolved in $880 \mathrm{ml}$ distilled water. The trace element solution was sterilized by filtration. Tryptic Soy Broth (TSB; $30 \mathrm{~g} \mathrm{l}^{-1}$ ) was used as a complete medium.

All Streptomyces strains were maintained on soy-flour mannitol agar (SMA) (Distler et al., 1985). S. griseus and mutant strains were routinely grown in 11 Erlenmeyer flasks containing $50 \mathrm{ml}$ medium at $29^{\circ} \mathrm{C}$. The seed cultures $(10 \mathrm{ml} \mathrm{MM})$ were inoculated with Streptomyces spores from SMA plates. Seed culture $(500 \mu \mathrm{l})$ grown for $4 \mathrm{~d}$ was used as an inoculum for the main cultures resulting in a final $\mathrm{OD}_{560}$ of $0 \cdot 1-0 \cdot 15$ (Kontron Uvikon 710 spectrophotometer). For the measurement of growth, nutrient concentrations, and intracellular nucleotide pools, $S$. griseus was fermented in 1.51 standard MM using a 21 fermenter model F-1000 (New Brunswick Scientific). The cultures were stirred at 300 r.p.m. at a temperature controlled to $29^{\circ} \mathrm{C}$. Air was supplied to the fermenter at a rate of $1.51 \mathrm{~min}^{-1}$. The $\mathrm{pH}$ and oxygen were continuously monitored throughout the experiment, but were not adjusted.

Measurement of growth. The growth was routinely controlled by measuring the $\mathrm{OD}_{560}$. Samples with $\mathrm{OD}_{560}$ values higher than 0.5 or 1.0 were diluted $1: 4$ or $1: 10$ with $\mathrm{MM}$ prior to measurement. The cell dry weight was determined by harvesting the mycelium by filtration through a nitrocellulose filter $(0.2 \mu \mathrm{m}$ pore size; Schleicher \& Schuell). Before determination of the weight, the mycelium was washed with $10 \mathrm{mM} \mathrm{NaCl}$ and the filters were dried at $65^{\circ} \mathrm{C}$ until the weight remained constant. Total cell protein was determined by the method described by
Virolle \& Bibb (1988), with the following modifications. The mycelium of $1 \mathrm{ml}$ culture was collected by centrifugation at 14000 r.p.m. The pellet was washed twice in distilled water and finally resuspended in $500 \mu \mathrm{l} \mathrm{H}_{2} \mathrm{O}$. The cells were disintegrated by sonication and the protein concentration was determined by the method of Bradford (1976), using BSA as a standard.

Medium transfer. For culture-shift experiments, S. griseus mycelium was harvested at the indicated times by centrifugation at 2000 r.p.m. for $5 \mathrm{~min}$ at $25^{\circ} \mathrm{C}$. The mycelia were subsequently resuspended in $2 \mathrm{ml} \mathrm{MM}$ at $29^{\circ} \mathrm{C}$. These cells were used to inoculate $50 \mathrm{ml}$ fresh $\mathrm{MM}$ to give a final $\mathrm{OD}_{560}$ of $0 \cdot 1$. Prior to inoculation, the fresh medium was placed in a 11 Erlenmeyer flask on a rotary shaker at $29^{\circ} \mathrm{C}$ for $1 \mathrm{~h}$. Further incubation of the shifted cultures was as described above.

Measurement of nutrient concentration. $S$. griseus was grown in $1.51 \mathrm{MM}$ at $29^{\circ} \mathrm{C}$. At given times, $2 \mathrm{ml}$ samples were taken and the supernatants were obtained by centrifugation at $10000 \mathrm{~g}$ for $15 \mathrm{~min}$. The supernatants were heated at $90^{\circ} \mathrm{C}$ for $10 \mathrm{~min}$ to inactivate any extracellular enzyme activity and stored at $-70^{\circ} \mathrm{C}$. The concentrations of $\mathrm{D}$-glucose and $\mathrm{L}$-asparagine were measured enzymically using D-glucose and L-asparagine assay kits (Boehringer), respectively. Ammonium concentrations were determined by a glutamate-dehydrogenase-based assay kit (Sigma). The concentration of phosphate was assayed colorimetrically using a commercially available assay (Merck). The values of $\mathrm{pH}$ and saturation of oxygen were determined continuously using electrodes Ingold 405/S7 (Roth) and YSI model 25 (Kipp \& Zonen), respectively.

The concentration of $\mathrm{Sm}$ was measured by a bioassay using a $\mathrm{Sm}$-sensitive and a Sm-resistant strain of Bacillus subtilis DSM 347 as described by Distler et al. (1985). A-factor was extracted and identified as described earlier (Horinouchi \& Beppu, 1992). The concentration of A-factor was assayed on SMA essentially as described by Horinouchi \& Beppu (1992). The S. griseus mutant strain M881 was used as an indicator for A-factor. Chemically synthesized A-factor (Funakoshi) was used as a standard.

Extraction and assay of nucleotides. The extraction and quantification of the intracellular pools of NTPs and of ppGpp were performed by an HPLC method as described elsewhere (Ochi, 1987a). Routinely, mycelium from 100-200 ml cultures was harvested by filtration on a nitrocellulose filter (pore size $0 \cdot 2 \mu \mathrm{m}$; Schleicher \& Schuell) and extracted. Finally the preparations were dissolved in $100 \mu \mathrm{H}_{2} \mathrm{O}$ and the NTPs and ppGpp were identified and quantified by co-chromatography with authentic standard solutions. A sample of ppGpp was kindly provided by A. Böck Institut für Genetic und Mikrobiologie, Universität München, Germany. The detection ranges for the NTPs and ppGpp were $>2$ pmol. Extracellular cAMP was assayed by reversed-phase HPLC using a $\mathrm{C}_{18}$-Partisil column $(4.6 \times 250 \mathrm{~mm}$; Beckman). After centrifugation at 14000 r.p.m., $100 \mu \mathrm{l}$ samples of culture supernatant were directly applied onto the column and subsequently eluted with a $90 \mathrm{ml}$ gradient (curve no. 4 of the System Gold; Beckman) from 0 to $40 \%(\mathrm{v} / \mathrm{v})$ solvent $\mathrm{B}(100 \%$ acetonitrile) with a flow rate of $1.5 \mathrm{ml} \mathrm{min}^{-1}$. Solvent A comprised $30 \mathrm{mM} \mathrm{KH}_{2} \mathrm{PO}_{4}$, $5 \mathrm{mM}$ tetrabutylammoniumhydrogen-sulfate and $2 \%(\mathrm{v} / \mathrm{v})$ acetonitrile, $\mathrm{pH} 6.0$. The elution of cAMP was assayed by the determination of $A_{260}$. cAMP was identified and quantified by co-chromatography with a standard solution of $10-100$ pmol cAMP. For the determination of the intracellular level of $\mathrm{cAMP}$, mycelium of a $200 \mathrm{ml}$ culture was extracted as described above, dissolved in $100 \mu \mathrm{H}_{2} \mathrm{O}$, and immediately analysed by HPLC.

Preparation of pulse-labelled protein samples. For pulsechase labelling of proteins, $S$. griseus N2-3-11 was grown in MM. 
At indicated times $150 \mu \mathrm{Ci}\left[{ }^{35} \mathrm{~S}\right] \mathrm{TRAN}-\mathrm{Mix}$ (specific activity > $37 \mathrm{TBq} \mathrm{mmol}^{-1}$; ICN Biochemicals) was added to $300 \mu$ l culture and incubated for an additional $20 \mathrm{~min}$. Subsequently, $10 \mu \mathrm{l}$ of a solution containing $10 \mathrm{mg} \mathrm{ml}^{-1}$ each of L-methionine and Lcysteine was added and the $S$. griseus was incubated for a further $10 \mathrm{~min}$. The cells were collected by centrifugation, washed twice in crack-buffer $(10 \mathrm{mM}$ Tris $/ \mathrm{HCl}, 5 \mathrm{mM}$ EDTA, $1 \mathrm{mM}$ PMSF and $5 \mathrm{mM} 2$-mercaptoethanol, $\mathrm{pH} \mathrm{7.4)} \mathrm{and} \mathrm{resuspended}$ in $100 \mu \mathrm{l}$ ice-cold crack-buffer. The mycelium was disintegrated by sonication (power $50 \%$, cycle $70 \%$, pulse $15 \mathrm{~s}$ ) using a sonifier model UW 60 (Bandelin). After sonication, $10 \mu \mathrm{l}$ of a solution containing $0.5 \%(\mathrm{w} / \mathrm{v})$ SDS and $10 \%(\mathrm{v} / \mathrm{v}) 2$ mercaptoethanol was added immediately and the sample was frozen in liquid nitrogen. To inactivate proteases, samples were incubated at $85^{\circ} \mathrm{C}$ for $15 \mathrm{~min}$. The samples were supplemented with $6 \mu \mathrm{l} 0.5 \mathrm{M} \mathrm{MgCl}_{2}$ prior to treatment with DNase I and RNase $A$ at concentrations of 100 and $40 \mu \mathrm{g} \mathrm{ml}^{-1}$, respectively. The nuclease treatment was performed at $5{ }^{\circ} \mathrm{C}$ for $30 \mathrm{~min}$. The samples were frozen in liquid nitrogen and lyophilized overnight, then resuspended in $100 \mu \mathrm{l} 2$-D sample buffer [ $9 \mathrm{M}$ urea, $4 \%(\mathrm{v} / \mathrm{v})$ Nonidet P-40, $1 \cdot 8 \%$ ampholytes $\mathrm{pH} 4-8,0 \cdot 2 \%$ ampholytes pH 3-10 (Promochem BDH) and 5 mM DTT] and centrifuged $(10 \mathrm{~min}, 10000 \mathrm{~g}$ ) prior to loading onto the IEF gel.

Two-dimensional (2-D) gel electrophoresis. 2-D gel electrophoresis of total cellular proteins was essentially as described by Garrels (1979). The gels were run with the ISO-DALT System (Hoefer Scientific). In the first dimension the proteins were separated in IEF gels $(280 \times 1.5 \mathrm{~mm})$. The IEF gel mixture had the following composition: $4.5 \%(\mathrm{w} / \mathrm{v})$ polyacrylamide, $8 \mathrm{M}$ urea, $2 \%$ Nonidet P-40, $1 \cdot 8 \%$ ampholytes $\mathrm{pH} 4-8$ and $0 \cdot 2 \%$ ampholytes pH 3-10. Each gel was loaded with approximately $2 \times 10^{6}$ c.p.m. trichloracetic-acid-precipitable material and the focusing of the proteins was achieved at $36 \mathrm{kV} \mathrm{h}^{-1}$ overnight. After electrophoresis, the IEF gels were equilibrated with $10 \mathrm{ml}$ ISO-equilibration buffer $(125 \mathrm{mM}$ Tris/ $\mathrm{HCl}, \mathrm{pH} 6.8,10 \%$ $(\mathrm{v} / \mathrm{v})$ glycerol, $2 \%$ SDS, $5 \mathrm{mM} 2$-mercaptoethanol and a trace of bromphenol blue) for $15 \mathrm{~min}$. Polyacrylamide gels (12.5\%) $(250 \times 220 \times 1.5 \mathrm{~mm}$; Laemmli, 1970$)$ containing $0.1 \%$ SDS were used for the second dimension. Separation of proteins was achieved at a constant voltage of $100 \mathrm{~V}$ for $22 \mathrm{~h}$ at $10^{\circ} \mathrm{C}$. The gels were incubated overnight in a solution of $10 \%(\mathrm{v} / \mathrm{v})$ acetic acid and $20 \%(\mathrm{v} / \mathrm{v})$ methanol. The gels were dried in a vacuum on a Whatman 3MM paper and the radioactively labelled proteins were visualized by autoradiography. The protein spots in the autoradiograms were quantified densitometrically using the BioImage system (Millipore) and Visage 110 (release 4.4) software.

\section{RESULTS}

\section{Growth of S. griseus N2-3-11 in a defined MM}

The growth of the Sm-overproducing strain S. griseus N23-11 in batch fermentation was determined by measuring the optical density, cell dry weight and total protein (Fig. 1). S. griseus N2-3-11 reproducibly showed a temporal phasing of growth and $\mathrm{Sm}$ production in the standard liquid MM employed in this study. The phasing was characterized by an initial lag phase, two EGPs separated by a short transient lag phase of reduced growth, and a stationary phase (Figs 1, 2a). Using mycelium from a stationary culture as inoculum, $S$. griseus entered the first EGP after a short lag of $0 \cdot 5-1 \mathrm{~h}$. The first EGP [duration $10 \mathrm{~h}$; doubling time $\left(t_{\mathrm{d}}\right)=4 \mathrm{~h}$ ] was followed by a diminution of growth ("transient lag phase'; $t_{\mathrm{d}}>8 \mathrm{~h}$ ) for

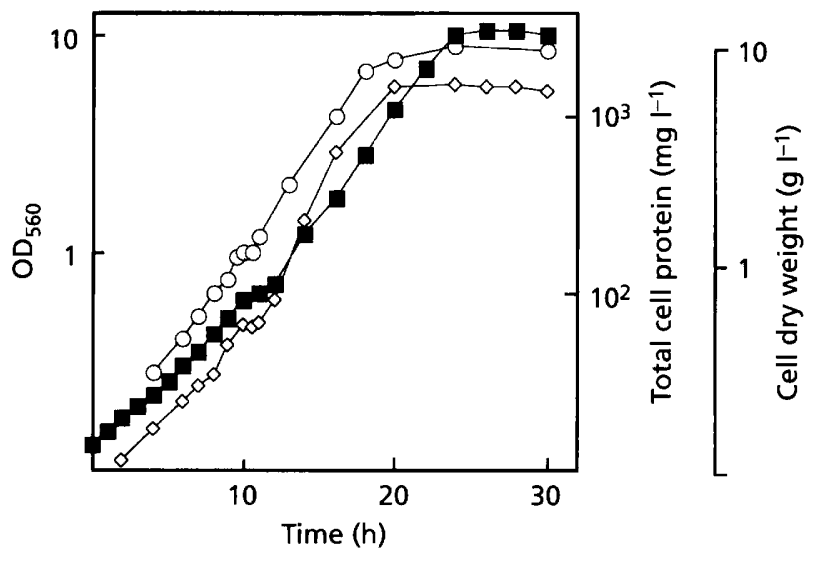

Fig. 1. Measurement of the growth of $S$. griseus N2-3-11 in standard defined medium. Growth was determined by measuring the optical density $(\boldsymbol{\square})$, total cell protein $(O)$ and cell dry weight $(\diamond)$.

at least $30-45 \mathrm{~min}$. Growth resumed and the culture entered the second EGP (duration $14 \mathrm{~h} ; t_{\mathrm{d}}=3 \mathrm{~h}$ ), showing a significantly higher rate of growth when compared to the first EGP. After $24 \mathrm{~h}$, the culture reached stationary phase. S. griseus N2-3-11 showed the same growth behaviour, with the exception of a prolonged initial lag phase of $16 \mathrm{~h}$, when spores were used as inoculum for the cultures (data not shown). The biphasic EGP and the positioning of the transient lag phase after $10 \mathrm{~h}$ growth were also found when the amount of biomass used as inoculum was changed by a factor of 0.5-4 (data not shown).

Since $S$. griseus was being grown in the presence of both glucose and L-asparagine, this chronological course of growth could easily be explained by the well-known diauxic growth of a bacterial population on carbon sources used sequentially. Therefore, the most important parameters such as biomass, $\mathrm{pH}$, and the concentrations of glucose, L-asparagine, ammonium, phosphate, dissolved oxygen, $\mathrm{Sm}$ and A-factor were measured during the course of a typical batch fermentation (Fig. $2 a-c$ ). Glucose and L-asparagine were consumed simultaneously throughout the growth of S. griseus. Under the conditions used, glucose and phosphate seemed to be the only nutrients to become exhausted in stationary phase (Fig. 2c). The concentration of dissolved oxygen did not fall below $85 \%$ at any point during the whole course of fermentation (Fig. 2b). The concentrations of ammonium and $\mathrm{L}$-asparagine remained in excess throughout the growth of $S$. griseus (Fig. 2c). The concentration of ammonium even increased after $24 \mathrm{~h}$ growth and reached a final concentration of $58 \mathrm{mM}$. Entering the stationary phase, the $\mathrm{pH}$ in the medium dropped to about 6.0 and started to increase after $30 \mathrm{~h}$, reaching values around $7 \cdot 8$ by the end of fermentation (stopped at $36 \mathrm{~h}$ ). The transient lag phase of $S$. griseus does not seem to be caused by diauxic growth, as during the period from 8 to $12 \mathrm{~h}$ there was no limitation of any nutrients in the culture. 


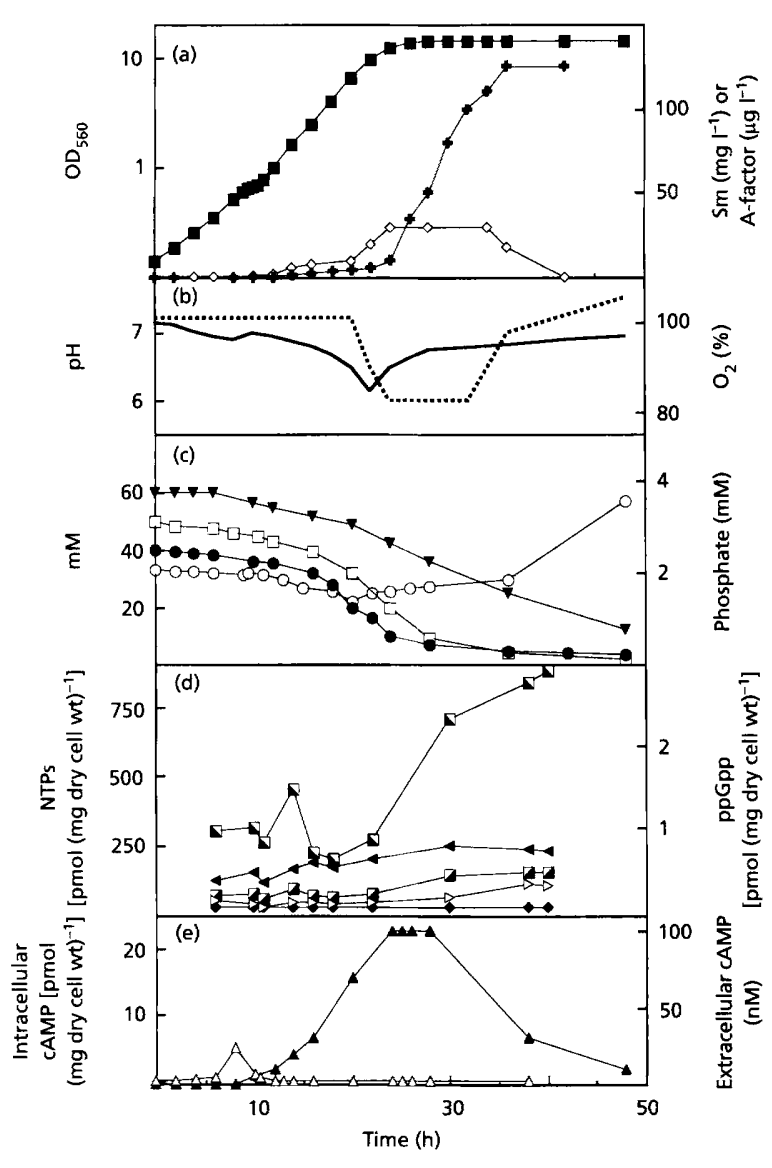

Fig. 2. Growth of $S$. griseus N2-3-11 in standard defined medium. (a) Production of biomass ( $\square$ ); Sm ( $\$$ ); A-factor in a 1.5 I batch culture of $S$. griseus N2-3-11 $(\diamond)$. (b) Concentration of oxygen $(-)$ and $\mathrm{pH}$ value (--) throughout the fermentation. (c) Concentrations of glucose ( $\square$ ), L-asparagine ( $\nabla$ ), ammonium (O) and phosphate (O) in the medium. (d) Intracellular concentrations of ATP ( $\nabla)$, GTP $(\nabla)$, CTP ( $\square)$, UTP ( $\Delta)$, and ppGpp (৫). (e) Intracellular $(\triangle)$ and extracellular $(\Delta)$ CAMP.

Although Sm was already detectable at a low concentration of about $0.5 \mathrm{mg} \mathrm{l}^{-1}$ after $14 \mathrm{~h}$ growth, its concentration increased dramatically only after $24 \mathrm{~h}$, when $S$. griseus entered stationary phase (Fig. 2a). The maximum Sm concentration of $115 \mathrm{mg} \mathrm{l}^{-1}$ was produced $36 \mathrm{~h}$ after inoculation under the standard conditions employed. No A-factor was detectable in the $S$. griseus cultures within the first $6 \mathrm{~h}$ growth. After the transient lag phase the concentrations of A-factor increased in parallel with growth reaching a maximum amount of approximately $30 \mu \mathrm{gl}^{-1}$ in early stationary phase. The concentration of A-factor decreased after $36 \mathrm{~h}$ growth and became undetectable in the culture supernatant or mycelium at the end of the fermentation (Fig. 2a).

Previously, Thompson and co-workers (Holt et al., 1992) reported that a similar pause during vegetative growth of S. bygroscopicus in complete medium was associated with dramatic changes in the intracellular levels of ppGpp and NTPs. Although $S$. grisens N2-3-11 was able to accumulate
Table 1. S. griseus strains used in this work

\begin{tabular}{|lcccl|}
\hline \multirow{2}{*}{ Strain } & \multicolumn{3}{c}{ Phenotype } & \multirow{2}{*}{ Reference/source } \\
\cline { 2 - 4 } & Sm* & A-factor $\dagger$ & Społ & \\
\hline N2-3-11 & + & + & + & Distler et al. (1985) \\
40236 & + & + & + & DSM $~$ \\
M881 & - & - & - & Distler et al. (1987) \\
W67 & - & + & - & Distler et al. (1990) \\
M66 & - & + & + & Distler et al. (1985) \\
\hline
\end{tabular}

* Sm production was measured on SMA.

† A-factor was extracted from cultures as described in Methods. The presence of A-factor was determined by the induction of production of Sm in strain M881.

$\ddagger$ Sporulation was analysed after growth on SMA for $3 \mathrm{~d}$.

$\S$ Deutsche Sammlung für Mikroorganismen, Braunschweig, Germany.

up to $50 \mathrm{pmol}(\mathrm{mg} \text { cell dry } \mathrm{wt})^{-1} \mathrm{ppGpp}$ in nutrient shift down experiments (data not shown), the amount of ppGpp was always below the level of detection during growth of $S$. griseus N2-3-11 in MM, even when as much as $500 \mathrm{mg}$ dry cell weight cells was extracted (Fig. 2d). In TSB complete medium, $S$. griseus produced ppGpp at a basal level of $3 \mathrm{pmol}(\mathrm{mg} \text { cell dry } \mathrm{wt})^{-1}$ during exponential growth and a maximum concentration of $10 \mathrm{pmol}(\mathrm{mg}$ cell dry wt) $)^{-1}$ after entering stationary phase, but no increased level of ppGpp was found during the transient lag phase (data not shown). The concentrations of GTP, UTP and CTP showed no significant alteration during the growth of S. griseus (Fig. 2d). On the other hand, the concentration of ATP had a basal level of 240-290 pmol ( $\mathrm{mg}$ cell dry wt $)^{-1}$ in the first and second EGP. A peak level of 480 pmol ( $\mathrm{mg}$ cell dry $\mathrm{wt})^{-1}$ ATP was detected in the transient lag phase. With the end of the second EGP, the concentration of ATP increased to $800 \mathrm{pmol}$ ( $\mathrm{mg}$ cell dry $w t)^{-1}$ by the end of the fermentation (Fig. 2d). As in the case of ppGpp, the intracellular level of cAMP was hardly detectable throughout the course of the batch fermentation; however, a peak concentration of 5 pmol $(\mathrm{mg} \text { cell dry } \mathrm{wt})^{-1} \mathrm{cAMP}$ was measured after $8 \mathrm{~h}$ growth, just before $S$. griseus entered the transient lag phase (Fig. 2e). Surprisingly, cAMP was found in concentrations as high as $100 \mathrm{nM}$ in the fermentation broth of S. griseus. Extracellular cAMP was detected in the medium supernatant for the first time when $S$. griseus passed the transient lag phase (Fig. 2e). The concentration of extracellular cAMP reached a maximum from 24 to $34 \mathrm{~h}$ growth and disappeared again during the late stationary phase (Fig. $2 \mathrm{e})$.

\section{Effects of variations in content of individual nutrients on the growth of S. griseus}

To analyse possible influences of the initial concentrations of the major nutrients in the medium on the growth curve, $S$. griseus N2-3-11 was cultivated in differently 
Decision phase regulation of streptomycin production

Table 2. Growth and Sm production of S. griseus N2-3-11 in different media

\begin{tabular}{|c|c|c|c|c|c|c|}
\hline \multirow[t]{2}{*}{ Medium } & \multicolumn{4}{|c|}{ Characteristics of growth phase } & \multicolumn{2}{|c|}{ Sm production } \\
\hline & $\begin{array}{l}\text { 1st EGP } t_{\mathrm{d}} \\
(\mathrm{h})^{*}\end{array}$ & $\begin{array}{l}\text { Transient } \\
\text { start at (h) }\end{array}$ & $\begin{array}{l}\text { 2nd EGP } t_{\mathrm{d}} \\
\text { (h) } \dagger\end{array}$ & $\begin{array}{l}\text { Stationary } \\
\text { start at (h) }\end{array}$ & $\begin{array}{c}\text { Initial } \\
\text { detection (h) }\end{array}$ & 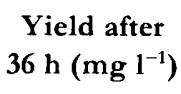 \\
\hline $\mathrm{MM}$ & $4 \cdot 2 \pm 0.5$ & 10 & $3 \cdot 0 \pm 0 \cdot 3$ & 24 & 14 & $115 \pm 10$ \\
\hline$+2 \times$ glucose & $4 \cdot 3 \pm 0 \cdot 2$ & 10 & $3 \cdot 1 \pm 0 \cdot 2$ & 24 & 14 & $85 \pm 10$ \\
\hline$+2 \times$ asparagine & $4 \cdot 2 \pm 0 \cdot 3$ & 10 & $3 \cdot 5 \pm 0 \cdot 2$ & 25 & 18 & $95 \pm 5$ \\
\hline$+2 \times$ ammonia & $4 \cdot 1 \pm 0 \cdot 2$ & 10 & $3 \cdot 1 \pm 0 \cdot 2$ & 25 & 18 & $90 \pm 5$ \\
\hline$+2 \times$ phosphate & $4 \cdot 3 \pm 0 \cdot 2$ & 10 & $3 \cdot 4 \pm 0.2$ & 25 & 23 & $50 \pm 5$ \\
\hline$+2 \times$ trace elements & $4 \cdot 2 \pm 0 \cdot 5$ & 10 & $3 \cdot 0 \pm 0 \cdot 1$ & 24 & 14 & $115 \pm 5$ \\
\hline$+5 \times$ ammonia & $4 \cdot 0 \pm 0 \cdot 1$ & 10 & $3 \cdot 3 \pm 0 \cdot 2$ & 25 & 22 & $65 \pm 5$ \\
\hline$+10 \times$ ammonia & $3 \cdot 9 \pm 0 \cdot 1$ & 10 & $3 \cdot 6 \pm 0 \cdot 2$ & 26 & 35 & $15 \pm 5$ \\
\hline $2 \times \mathrm{MM}$ & $4 \cdot 3 \pm 0 \cdot 4$ & 10 & $3 \cdot 7 \pm 1 \cdot 0$ & 26 & 23 & $20 \pm 5$ \\
\hline TSB & $2 \cdot 3 \pm 0 \cdot 1$ & 5 & $1 \cdot 25 \pm 0 \cdot 1$ & 12 & 22 & $40 \pm 5$ \\
\hline
\end{tabular}

* Determined for the period $2-9 \mathrm{~h}$, or $1-4 \mathrm{~h}$ for TSB.

tDetermined for the period $11-24 \mathrm{~h}$, or $6-10 \mathrm{~h}$ for TSB.

Table 3. Growth characteristics and Sm production in cultures of various S. griseus wild-type and mutant strains grown in defined MM

\begin{tabular}{|c|c|c|c|c|c|c|}
\hline \multirow[t]{2}{*}{ Strain } & \multicolumn{4}{|c|}{ Characteristics of growth phase } & \multicolumn{2}{|c|}{ Sm production } \\
\hline & $\begin{array}{c}\text { 1st EGP } t_{\mathrm{d}} \\
(\mathrm{h})^{*}\end{array}$ & $\begin{array}{c}\text { Transient } \\
\text { start at (h) }\end{array}$ & $\begin{array}{c}\text { 2nd EGP } t_{\mathrm{d}} \\
\text { (h) } \dagger\end{array}$ & $\begin{array}{l}\text { Stationary } \\
\text { start at (h) }\end{array}$ & $\begin{array}{c}\text { Initial } \\
\text { detection }(h)\end{array}$ & 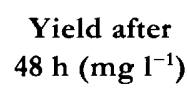 \\
\hline $\mathrm{N} 2-3-11$ & $4 \cdot 2 \pm 0 \cdot 5$ & 10 & $3 \cdot 0 \pm 0 \cdot 3$ & 24 & 14 & $115 \pm 10$ \\
\hline DSM 40236 & $4 \cdot 2 \pm 0 \cdot 4$ & 10 & $2 \cdot 9 \pm 0 \cdot 1$ & 24 & 36 & $30 \pm 20$ \\
\hline M881 & $4 \cdot 7 \pm 0 \cdot 5$ & 10 & $3 \cdot 1 \pm 0 \cdot 5$ & 24 & - & 0 \\
\hline $\mathrm{M} 881+\mathrm{A}$-factor $\ddagger$ & $4 \cdot 9 \pm 0.5$ & 10 & $3 \cdot 0 \pm 0.5$ & 24 & 13 & $100 \pm 10$ \\
\hline M66 & $4 \cdot 2 \pm 0 \cdot 5$ & 10 & $2 \cdot 9 \pm 0 \cdot 3$ & 24 & $\ldots$ & $\overline{0}$ \\
\hline W67 & $3.9 \pm 0.5$ & $3 \cdot 5$ & $2 \cdot 4 \pm 0 \cdot 1$ & 22 & - & 0 \\
\hline
\end{tabular}

* Determined for the period $2-9 \mathrm{~h}$, or $0-3 \mathrm{~h}$ for W67.

†Determined for the period 11-20 h, or 5-18 h for W67.

$\ddagger$ Grown in the presence of $2 \mathrm{mg} \mathrm{A}$-factor $\mathrm{l}^{-1}$.

composed MM and TSB complete medium (Table 2). There was no significant alteration in growth and Sm production of $S$. griseus when the concentration of all or of single components of the MM were increased by a factor of 2-10 (Table 2, not all data shown). The growth of $S$. griseus always showed two EGPs separated by the transient lag phase $10 \mathrm{~h}$ post-inoculation. The rates of growth within the first and second EGPs were not significantly changed by the various alterations of the synthetic medium. In contrast, the time-course of Sm production and its maximal yield varied considerably under the same conditions (Table 2).

In TSB, S. griseus also showed a biphasic EGP, separated by a transient lag phase after $5 \mathrm{~h}$ growth. The growth rates within the two EGPs were almost doubled to 0.3 and 0.55 , respectively, as compared to those found in synthetic medium (Table 2). After $12 \mathrm{~h}$ growth, S. griseus entered the stationary phase and $\mathrm{Sm}$ was detected for the first time after $22 \mathrm{~h}$. Comparing the characteristics of growth of $S$. griseus in the minimal and complete media, it was conspicuous that $S$. griseus cells entered the transient lag phase on both media after growing exponentially for approximately 2.5 generations. Therefore, the general course of growth of $S$. griseus, but not the production of $\mathrm{Sm}$, seems to be independent of the medium. This probably reflects a programmed developmental cycle, as already postulated by Ensign (1988).

\section{Growth of other S. griseus strains and mutants deficient in differentiation}

The growth of $S$. griseus N2-3-11 used as the principal strain in our investigations was compared to that of the Waksman strain (DSM 40236) and mutants of strain N2- 


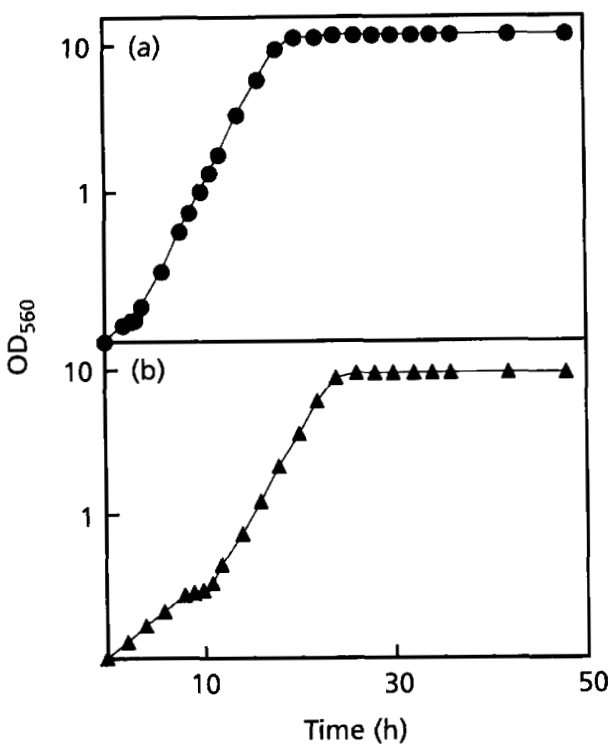

Fig. 3. Growth of the $S$. griseus N2-3-11 mutant strains W67 (0) and $M 881(\boldsymbol{A})$ in standard MM determined by measuring the optical density.

3-11 (Table 3, Fig. 3). These mutants were M66, unable to produce $\mathrm{Sm}$, and the pleiotropic mutants M881 (A-factordeficient; Distler et al., 1990, 1992) and W67 (A-factorinsensitive; Distler et al., 1990), both lacking secondary metabolism and differentiation. The $S$. griseus wild-type strain DSM 40236 and strains M66 and M881, grown with or without A-factor, showed the same biphasic EGP interrupted by the transient growth phase after $10 \mathrm{~h}$ growth. The $t_{\mathrm{d}}$ of these $S$. griseus strains within the first and the second EGPs were roughly the same as in strain N2-3-11 (Table 3). The time-course and yield of Sm by the mutant M881 grown in the presence of A-factor was very similar to that of the overproducing strain $S$. griseus N2-311. Sm was detectable in the culture supernatant for the first time after $13 \mathrm{~h}$ growth and a maximal amount of $100 \mathrm{mg} \mathrm{Sm} \mathrm{l}^{-1}$ was found after $36 \mathrm{~h}$ growth. In contrast, in the cultures of $S$. griseus DSM $40236 \mathrm{Sm}$ was reproducibly detectable only after $36 \mathrm{~h}$ growth. A maximal amount of $30 \mathrm{mg} \mathrm{Sm} \mathrm{l}^{-1}$ was produced after $72 \mathrm{~h}$. No Sm production was detected in the cultures of $S$. griseus mutants M66 and M881, grown without A-factor. Therefore, the overall time-course and phasing growth of $S$. griseus is independent of its ability to produce either Afactor or Sm.

In contrast to the growth characteristics of all the other $S$. griseus wild-type and mutant strains analysed so far, that of strain W67 deviated significantly (Table 3, Fig. 3). Although the growth rate of W67 within the first EGP was comparable to the other $S$. griseus strains, the onset of the transient lag phase reproducibly occurred after $3.5 \mathrm{~h}$, equivalent to one generation of exponential growth. Also, within the second EGP, strain W67 showed a higher growth rate as compared to all other $S$. griseus strains.

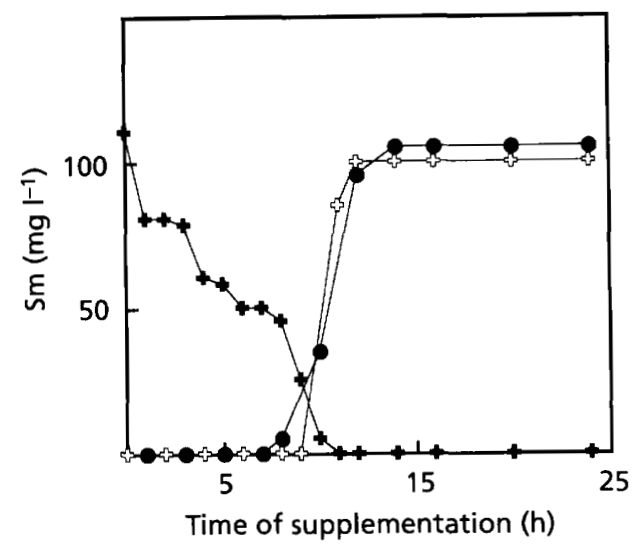

Fig. 4. Induction or repression of Sm synthesis and dependence of the time of addition of effector molecules. The yield of $\mathrm{Sm}$ produced after $48 \mathrm{~h}$ by $\mathrm{M} 881$ and $S$. griseus N2-3-11 supplemented at the indicated time with effector molecules: M881 with $2 \mathrm{mg} \mathrm{A-factor} \mathrm{I}^{-1}$ (4); S. griseus N2-3-11 with $50 \mathrm{mM}$ L-valine (§) or $10 \mu \mathrm{M}$ staurosporine (O).

\section{Biological relevance of the first EGP for the production of $\mathrm{Sm}$}

The biosynthesis of $\mathrm{Sm}$ in various strains of $S$. griseus is repressible by either L-valine (Ensign, 1988) or protein kinase inhibitors like staurosporin (Hong et al., 1993). In the $S$. griseus mutant strain M881, deficient in A-factor synthesis, Sm production can be restored to wild-type levels by addition of exogenous A-factor (Khokhlov, 1982). A-factor showed the strongest effect when added to a culture of M881 at the time of inoculation, suggesting the existence of a physiological state soon after start of growth (or during the preceding stationary phase) in which the action of A-factor is required, the A-factorsensitive stage. To analyse this assumption in detail, parallel cultures of M881 were supplemented at different times with $2 \mu \mathrm{g} \mathrm{A}$-factor $\mathrm{ml}^{-1}$ and the yield of Sm produced after $48 \mathrm{~h}$ growth was determined (Fig. 4). The effect of A-factor on the induction of $\mathrm{Sm}$ synthesis was strictly dependent on the age of the M881 culture. Afactor $\left(2 \mu \mathrm{g} \mathrm{ml}^{-1}\right)$ added at the beginning of fermentation induced the production of $110 \mathrm{mg} \mathrm{Sm} \mathrm{l}^{-1}$. The final amount of Sm produced dropped, reaching non-detectable levels, when A-factor was added upon entering the transient lag phase. In cultures of M881, there was no induction of $\mathrm{Sm}$ production when $\mathrm{A}$-factor was added up to concentrations as high as $20 \mu \mathrm{g} \mathrm{ml}^{-1} 10 \mathrm{~h}$ after inoculation or later (Fig. 4, not all data shown). Also, the repression of Sm synthesis in the $S$. griseus wild-type by Lvaline and staurosporin was found to be dependent on the age of the culture. Within the first $10 \mathrm{~h}$ growth, addition of either valine or staurosporin repressed the production of Sm without affecting the time-course of growth or the amount of biomass produced (Fig. 4 , and data not shown). However, there was no repression of $\mathrm{Sm}$ production when these inhibitors were added to a culture of $S$. griseus which had already passed the transient lag phase after $10 \mathrm{~h}$ growth (Fig. 4). 


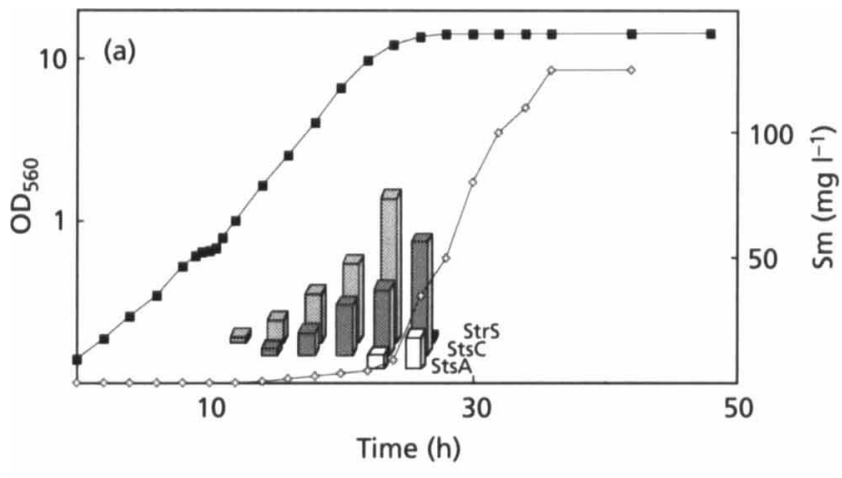

(b)

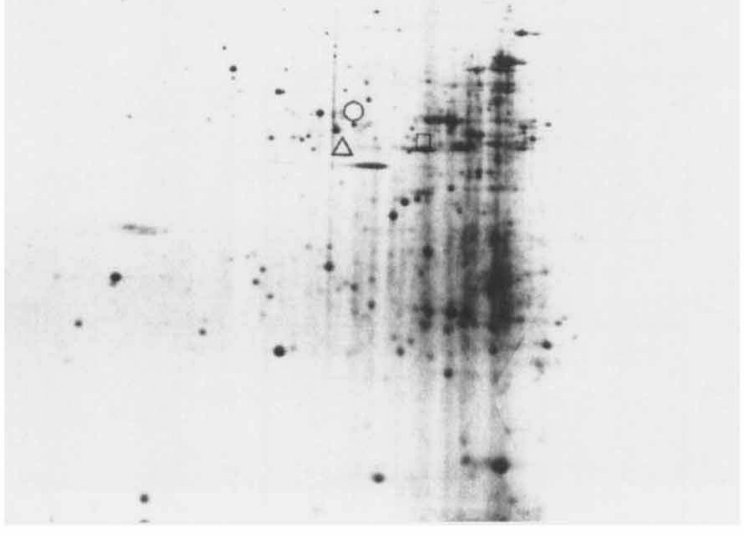

(c)

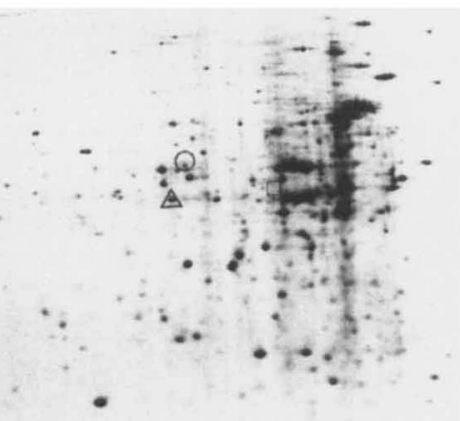

-

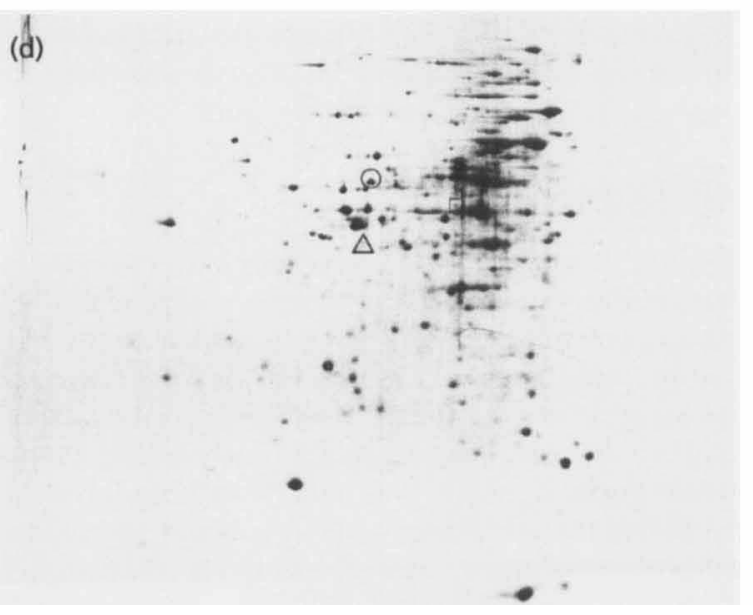

\section{Growth-phase-dependent expression of Sm biosynthetic genes}

The growth-phase-dependent expression of three Sm biosynthetic genes, sts $C$ encoding the L-glutamine: scylloinosose aminotransferase, and the related putative aminotransferase genes sts $A$ and str $S$, each located in a different transcription unit of the $S$. griseus str/sts gene cluster (Retzlaff et al., 1993; Piepersberg, 1995) were analysed using two-dimensional gel electrophoresis of $\left[{ }^{35} \mathrm{~S}\right]$ methionine pulse-labelled proteins of $S$. griseus N2-311 (Fig. 5a). The StrS, StsA, and StsC proteins were identified by co-migration with these proteins individually overexpressed from the $\mathrm{T} 7$ promoter in E. coli recombinant strains (J. Ahlert, personal communication). 2-D electrophoregrams from several independent experiments were analysed and the relative rates of expression were calculated (Fig. 5a). No expression of proteins StrS, Sts A and $\mathrm{Sts} C$ was found during the first EGP (Fig. 5a, b). The expression of the proteins StsC and StrS is characterized by an increasing level of synthesis during the second EGP reaching a maximal expression rate in the SGP (Fig. 5a). The expression of StrS was already detectable $2 \mathrm{~h}$ after the transient lag phase. It reached a peak of synthesis $22 \mathrm{~h}$ post-inoculation and no expression of StrS was found in stationary phase after $24 \mathrm{~h}$ (Fig. 5a, c, d). The protein $\mathrm{Sts} C$ was found to be expressed for the first time after $14 \mathrm{~h}$ growth and the rate of expression reached a maximum after $24 \mathrm{~h}$ (Fig. 5a, d). In contrast, the protein Sts A was detectably synthesized only during early stationary phase between 20 and $24 \mathrm{~h}$ growth (Fig. 5a,d). These results showed that at least two of the $\mathrm{Sm}$ biosynthetic genes were expressed immediately after the $S$. griseus culture had passed the transient lag phase and entered the second EGP, during which the factor-induced physiological switch is executed. This explains the synthesis of $\mathrm{Sm}$ already within the second EGP. Thus the decision-making process in $S$. griseus, to produce $\mathrm{Sm}$, became irreversible within the first $10 \mathrm{~h}$ growth (first EGP), with the susceptibility for signals inducing secondary metabolism and cell differentiation being highest at the time immediately after inoculation. Hence, we define the first EGP as a factor-sensitive 'decision phase' and the second EGP as an 'execution phase' which cannot be further influenced by external switch-setting factors. The transient lag phase is called the 'decision lag'.

\section{Decision phase model of the Sm production and developmental cycle of S. griseus}

To further understand the physiological characteristics of the two EGPs, several shift experiments were carried out.

Fig. 5. Growth, $5 \mathrm{~m}$ production and kinetics of the expression of selected Sm biosynthetic genes of S. griseus N2-3-11 in standard MM. (a) Bar graphs show the relative expression rates of the pulse-labelled StrS, StsA, and StsC proteins, which were resolved in 2-D gel autoradiograms and densitrometrically quantified using Visage software. The production of biomass $(\square)$ and Sm (ङ) are indicated. (b-d) Autoradiography of 2-D gels of S. griseus proteins pulse-labelled after $8 \mathrm{~h}(\mathrm{~b}), 18 \mathrm{~h}$ (c) and $24 \mathrm{~h}$ (d). The positions of the proteins StrS $(\triangle)$ StsA $(\square)$ and StsC $(O)$ are shown. 

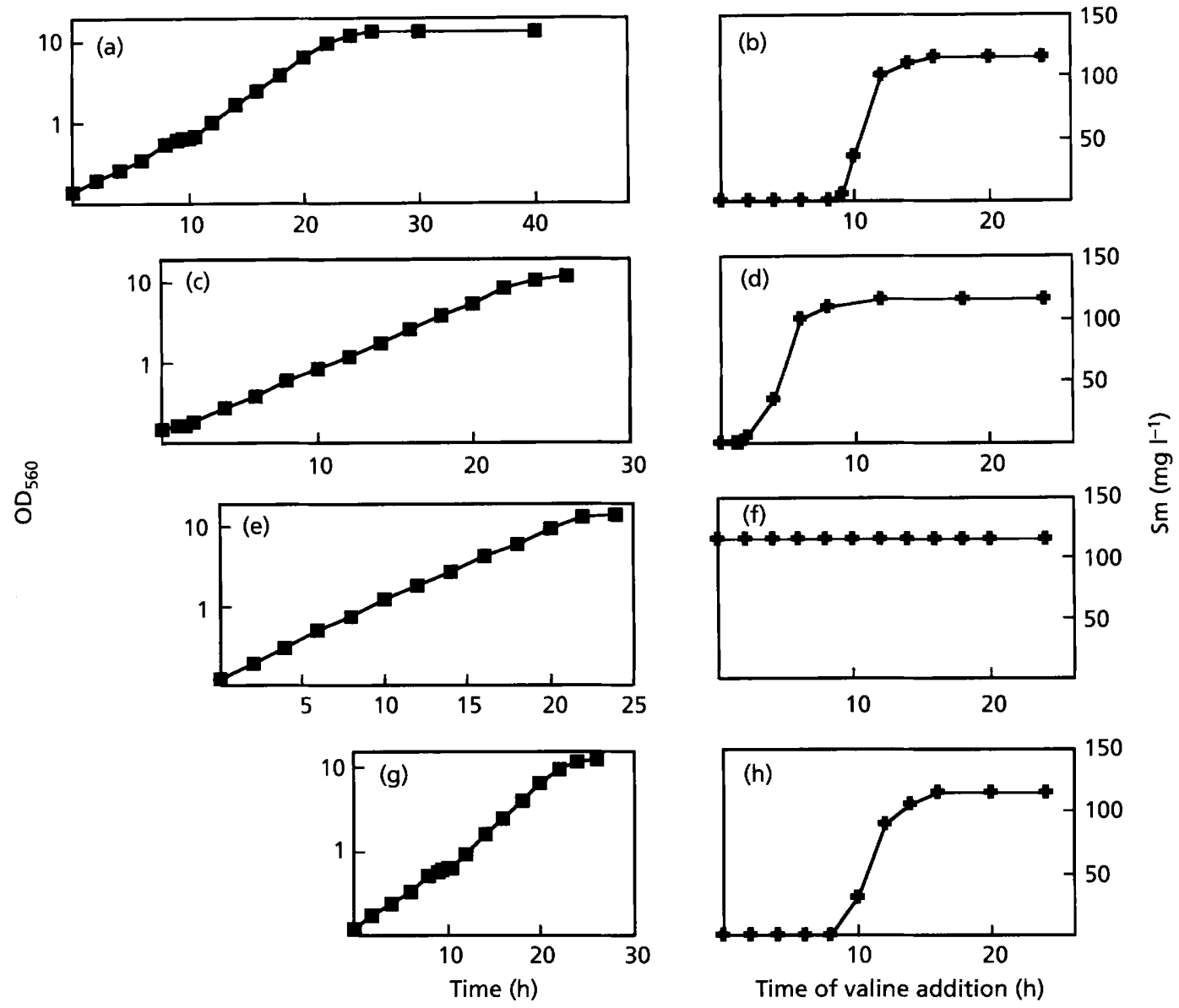

Fig. 6. Time-course of growth of $S$. griseus cells shifted from a primary culture (a) into fresh $\mathrm{MM}$ after $8 \mathrm{~h}$ (c), $12 \mathrm{~h}$ (e) and $24 \mathrm{~h}(\mathrm{~g})$ growth. Growth was determined by measuring the optical density. (b, $d, f, h)$ Determination of the time period in which the $\mathrm{Sm}$ production of $\mathrm{S}$. griseus was sensitive to repression by L-valine. Sm production after $48 \mathrm{~h}$ in the primary culture (b) and the $8 \mathrm{~h}(\mathrm{~d}), 12 \mathrm{~h}(\mathrm{f})$ and $24 \mathrm{~h}(\mathrm{~h})$-shift cultures supplemented at the indicated times with $50 \mathrm{mM}$ L-valine are shown.

S. griseus mycelium grown for different times in standard synthetic medium was shifted into fresh medium. The time-course of growth of the shift cultures was then analysed by (1) measuring the optical density of the cultures and (2) by determining the time period in which the production of $\mathrm{Sm}$ was sensitive to repression by $\mathrm{L}-$ valine (Fig. 6). When $S$. griseus cells grown for $8 \mathrm{~h}$ were shifted into fresh MM, the culture entered a decision lag phase after an additional $2 \mathrm{~h}$, corresponding to the overall time between inoculation and the onset of the transient growth phase in the primary culture (Fig. 6c). Also, Lvaline only repressed the synthesis of $\mathrm{Sm}$ when added to the 8 -h-shift culture within the first $2 \mathrm{~h}$ growth. Therefore, the first EGP or decision phase in the 8-h-shift culture was reduced to a period of $2 \mathrm{~h}$ (Fig. 6d). When $S$. griseus cells which had entered the second EGP were transferred after 12, 14 or $16 \mathrm{~h}$ into fresh medium (Fig. 6e, and data not shown), these cultures continued to grow exponentially but without a decision lag, entering stationary phase after $24 \mathrm{~h}$. Consistent with these results, there was no repression of $\mathrm{Sm}$ synthesis in cultures shifted after
$12-16 \mathrm{~h}$ when $\mathrm{L}$-valine was added at any time thereafter (Fig. 6f, and data not shown). The regular time-course of growth in the shifted cultures was regained when $S$. griseus cells were transferred from the stationary phase of the primary culture into fresh medium (Fig. 6g). Thus the 24h-shift culture exhibited all normal growth phases, and Lvaline added within the first $10 \mathrm{~h}$ growth was again able to repress the production of $\mathrm{Sm}$ (Fig. 6h).

\section{DISCUSSION}

The initial studies of the life-cycle of a Streptomyces strain in batch culture presented here were initiated to obtain a more fundamental and precise knowledge of the various physiological stages of the growth of Streptomyces. This knowledge is a prerequisite for further analyses of the processes governing secondary metabolism and cell differentiation. $S$. griseus was chosen as a model organism since it has the advantages of both being an intensively studied streptomycete and reproducibly showing all the features of a normal life-cycle in a defined medium, 
including sporulation and antibiotic production (Shapiro, 1989; Distler et al., 1990, 1992; Ensign, 1988). We have shown that the vegetative or exponential growth of various $\mathrm{Sm}$-producing and A-factor-dependent strains of $S$. griseus follow medium-independent biphasic kinetics. This behaviour is caused by passing through a phase named 'decision lag' during which the cells undergo a fundamental change regarding their sensitivity to signals inducing or repressing differentiation and secondary metabolism. Under normal conditions, a strain-specific signalling cascade induces the decision-making process in the early vegetative growth phase ('decision phase'; Fig. 1). As the culture enters the 'decision lag', the decisionmaking process is completed and seems to become unchangeable within the second EGP which might be regarded as an 'execution phase' (Fig. 6). Later, during the interval between 18 and $24 \mathrm{~h}$ growth of a standard batch culture, the cells return again to a state in which they are sensitive to external signal molecules priming them for a following round of decision-making events.

In the case of several strains of S. griseus, comprising isolates producing $\mathrm{Sm}$, leucaemomycin, nonactin and daunorubicin, A-factor is a basic and essential effector of the switch-inducing machinery (Eritt et al., 1984; Horinouchi \& Beppu, 1994). To induce Sm synthesis, Afactor needs to be present either during the stationary phase or directly upon onset of growth in the early vegetative growth phase of $S$. griseus. This is suggested by the rapid loss of A-factor-sensitivity of an A-factornegative mutant (strain M881) directly after the onset of growth, with the complete abolition of any effects of Afactor addition when the decision lag is reached (Fig. 4). In contrast to this observation, the highest productivity for A-factor in the culture is at the beginning of stationary phase (Figs 2 and 4). Therefore it is tempting to speculate that (1) the much higher level of A-factor in the second EGP is necessary for the complete induction of sporulation or (2) the extracellular A-factor is responsible for inducing the mechanism(s) for the switch back to the signalling-sensitive state, possibly via the activation of membrane-bound GTPases (Penyige et al., 1992).

Although A-factor is currently the only known signal molecule switching the cultures towards cell differentiation and secondary metabolism, other still-unknown factors or physiological effects could also be prerequisites for a successful decision-making process in $S$. griseus or other Streptomyces species. For example, this view is supported by the availability of other types of pleiotropic mutants, such as the $S$. griseus mutant strain W67, in which differentiation and secondary metabolism are suppressed by events which probably do not influence the A-factordependent cascade (Distler et al., 1990; Babcock \& Kendrick, 1988). The $S$. griseus mutant strain W67 seems to be impaired in the programmed cell-cycle which possibly brings about its A-factor-insensitive pleiotropic deficiency. The properties of the differentiation-cycle mutant W67 support the concept that the course of growth of $S$. griseus described here is based on a genetically determined programme. Internal components of the signalling cascade could be G-proteins (Penyige et al.,
1992), as well as protein kinases/phosphatases and inhibitors thereof (Hong et al., 1993). The participation of protein kinases in the switch-setting process is supported by the growth-phase-dependent repression of Sm synthesis in $S$. griseus by staurosporin (Fig. 4).

ppGpp has also been postulated to be involved in the induction of secondary metabolism in Sm-producing $S$. griseus (Ochi, 1987b). However, the data presented in this report do not support a direct correlation between the accumulation of ppGpp and the decision-switch phenomenon. Indeed, there was no accumulation of ppGpp during the growth of $S$. griseus N2-3-11 in the synthetic medium used. This in turn suggests that regulatory processes based on the stringent response phenomenon are not a prerequisite for the induction of the secondary metabolism in $S$. griseus. Similar results were previously reported for other streptomycetes (Bascarán et al., 1991). Another generally distributed intracellular signal molecule in bacteria, cAMP, which was discussed as being involved in the regulation of aminoglycoside production in Streptomyces species (Ragan \& Vining, 1978), is accumulated intracellularly in $S$. griseus just before the culture enters the decision phase lag (Fig. 2). Whether the intracellular peak level of cAMP is the stimulus for the diminution of growth during the decision lag or simply another phenomenon accompanying the decision-making process will have to be investigated in the future. There is also no experimental evidence available that the cAMP found in the culture supernatant at the beginning of the SGP is correlated with events switching the culture back towards a signal-sensitive state (see above). The biochemical mechanism(s) of the L-valine-dependent physiological effect(s) leading to the repression of secondary metabolism (Fig. 4) and of sporulation in S. griseus N2-311 is still unclear. The L-valine-dependent effect in $S$. griseus strain 2682 is explained by the observed repression of A-factor synthesis (Ensign, 1988). However, A-factor biosynthesis is not inhibited by L-valine in $S$. griseus N23-11, nor does A-factor relieve the valine effect when added in concentrations up to $10 \mathrm{mg} \mathrm{l}^{-1}$ (data not shown). Further investigations into the processes involved must be conducted with these different $S$. griseus strains to explain the conflicting results.

These results suggest that a decision-making process occurs during the first EGP of the $S$. griseus fermentation, in which secondary metabolism and cell differentiation are switched on. This phenomenon is probably a generally distributed property of streptomycetes and other actinomycetes. This concept is supported by the description of a biphasic exponential growth behaviour of $S$. bygroscopicus and S. coelicolor in batch fermentations (Holt et al., 1992; Blanco et al., 1994). Therefore, the traditional picture of the growth of Streptomyces having a uniform vegetative growth phase has to be changed to a more complex one. There is no longer only a vegetative growth phase in which biomass is accumulated, followed by a SGP 'responsible' for the production of secondary metabolites and sporulation. Instead, we postulate the presence of an intrinsic physiological cycle only in the course of which the regulatory switch-settings for metabolic and cell 
differentiation can be made. During the first EGP, the decision to switch to the genetic programme(s) for later differentiation and secondary metabolite production can be induced by general or strain-specific effector molecules. The cells are then committed to secondary metabolism. If this decision lag has been passed without switch-inducing conditions and the second EGP has been entered, these decision-making processes are transiently blocked until resuming a sensitive, decision-prone state after entering the SGP. The nature of the physiological block in the post-decision phase, and the mechanism(s) of returning to the state in which cells become sensitive to A-factor or Lvaline, are the most interesting phenomena for an understanding on the molecular level of this type of control of a differentiation cycle in streptomycetes.

\section{ACKNOWLEDGEMENTS}

We thank August Böck for the sample of ppGpp and Annette Mehling for the critical reading of the manuscript. This work has been supported in part by grants from the Deutsche Forschungsgemeinschaft and the Bundesministerium für Forschung und Technologie.

\section{REFERENCES}

Babcock, M. J. \& Kendrick, K. E. (1988). Cloning of DNA involved in sporulation of Streptomyces griseus. J Bacteriol 170, 2802-2808.

Bascarán, V., Sánchez, L., Hardisson, C. \& Braña, A. F. (1991). Stringent response and initiation of secondary metabolism in Streptomyces clavuligerus. J Gen Microbiol 137, 1625-1634.

Blanco, G., Rodicio, M. R., Puglia, A. M., Mendez, C., Thomson, C. J. \& Salas, J. A. (1994). Synthesis of tibosomal proteins during growth of Streptomyces coelicolor. Mol Microbiol 12, 375-385.

Bradford, M. M. (1976). A rapid and sensitive method for the quantitation of microgram quantities of proteins utilizing the principle of protein-dye binding. Anal Biocbem 72, 248-254.

Demain, A. L. (1989). Carbon source regulation of idiolite biosynthesis in actinomycetes. In Regulation of Secondary Metabolism in Actinomycetes, pp. 127-134. Edited by S. Shapiro. Boca Raton, FL: CRC Press.

Distler, J., Klier, K., Piendl, W., Werbitzky, O., Böck, A., Kresze, G. \& Piepersberg, W. (1985). Streptomycin biosynthesis in Streptomyces griseus. I. Characterisation of streptomycin-idiotrophic mutants. FEMS Microbiol Lett 30, 145-150.

Distler, J., Mansouri, K., Ebert, A., Pissowotzki, K., Stockmann, M. \& Piepersberg, W. (1987). Gene cluster for streptomycin biosynthesis in Streptomyces griseus: nucleotide sequence of three genes and analysis of transcriptional activity. Nucleic Acids Res 15, 8041-8056.

Distler, J., Mayer, G. \& Piepersberg, W. (1990). Regulation of biosynthesis of streptomycin. In Proceedings of the 6th International Symposium on Genetics of Industrial Microorganisms '90, vol. 1, pp. 379-392. Edited by H. Heslot, J. Davies, J. Florent, L. Bobichon, G. Durand \& L. Penasse. Paris: Société Française de Microbiologie.

Distler, J., Mansouri, K., Mayer, G., Stockmann, M. \& Piepersberg, W. (1992). Streptomycin production and its regulation. Gene 115, 105-111.

Ensign, J. C. (1988). Physiological regulation of sporulation of Streptomyces griseus. In Biology of Actinomycetes '88, pp. 309-315. Edited by Y. Okami, T. Beppu \& H. Ogawara. Tokyo: Japan Scientific Societies Press.
Eritt, I., Grafe, U. \& Fleck, W. F. (1984). Inducers of both cytodifferentiation and anthracycline biosynthesis of Streptomyces griseus and their occurrence in actinomycetes and other microorganisms. Z Allg Mikrobiol 24, 3-12.

Garrels, J. I. (1979). Two-dimensional gel electrophoresis and computer analysis of proteins synthesized by clonal cell lines. $J$ Biol Chem 254, 6961-6977.

Holt, T. G., Chang, C., Laurent-Winter, C., Murakami, T., Garrels, J. I., Davies, J. E. \& Thompson, C. J. (1992). Global changes in gene expression related to antibiotic synthesis in Streptomyces bygroscopicus. Mol Microbiol 6, 969-980.

Hong, S., Matsumoto, A., Horinouchi, S. \& Beppu, T. (1993). Effects of protein kinase inhibitors on in vitro protein phosphorylation and cellular differentiation of Streptomyces griseus. Mol Gen Genet 236, 347-354.

Hopwood, D. A. \& Sherman, D. H. (1990). Molecular genetics of polyketides and its comparison to fatty acid biosynthesis. Annu Rev Genet 24, 37-66.

Horinouchi, S. \& Beppu, T. (1992). Regulation of secondary metabolism and cell differentiation in Streptomyces: A-factor as microbial hormone and the AfsR protein as a complement of a twocomponent regulatory system. Gene 115, 167-172.

Horinouchi, S. \& Beppu, T. (1994). A-factor as a microbial hormone that controls cellular differentiation and secondary metabolism in Streptomyces griseus. Mol Microbiol 12, 859-864.

Khokhlov, A. S. (1982). Low molecular weight microbial bioregulators of secondary metabolism. In Overproduction of Microbial Products, pp. 97-109. Edited by V. Krumphanzel, B. Sikyta \& Z. Vanek. London: Academic Press.

Laemmli, U. K. (1970). Cleavage of structural proteins during the assembly of the head of bacteriophage T4. Nature 227, 680-685.

Martin, J. F. (1989). Molecular mechanisms for the control by phosphate of the biosynthesis of antibiotics and secondary metabolites. In Regulation of Secondary Metabolism in Actinomycetes, pp. 213-237. Edited by S. Shapiro. Boca Raton, FL: CRC Press.

Ochi, K. (1987a). Changes in nucleotide pools during sporulation of Streptomyces griseus in submerged culture. $J$ Gen Microbiol 133, 2787-2795.

Ochi, K. (1987b). Metabolic initiation of differentiation and secondary metabolism by Streptomyces griseus: significance of the stringent response (ppGpp) and GTP content in relation to Afactor. J Bacteriol 169, 3608-3616.

Penyige, A., Vargha, G., Ensign, J. C. \& Barabás, G. (1992). The possible role of ADP ribosylation in physiological regulation of sporulation in Streptomyces griseus. Gene 115, 181-185.

Piepersberg, W. (1995). Streptomycin and related aminoglycosides. In Biochemistry and Genetics of Antibiotic Production, pp. 531-570. Edited by L. C. Vining \& C. Stuttard. Newton, MA: Butterworth-Heinemann.

Ragan, C. M. \& Vining, L. C. (1978). Intracellular cyclic adenosine $3^{\prime}, 5^{\prime}$-monophosphate levels and streptomycin production in cultures of Streptomyces griseus. Can J Microbiol 24, 1012-1015.

Retzlaff, L. \& Distler, J. (1995). The regulator of streptomycin gene expression, StrR, of Streptomyces griseus is a DNA binding activator protein with multiple recognition sites. Mol Microbiol 18, 151-162.

Retzlaff, L., Mayer, G., Beyer, S., Ahlert, J., Verseck, S., Distler, J. \& Piepersberg, W. (1993). Streptomycin production in streptomycetes: a progress report. In Industrial Microorganisms: Basic and Applied Molecular Genetics, pp. 183-194. Edited by R. H. Baltz, G. D. Hegeman \& P. L. Skatrud. Washington, DC: American Society for Microbiology. 
Decision phase regulation of streptomycin production

Shapiro, S. (1989). Nitrogen assimilation in actinomycetes and the influence of nitrogen nutrition on actinomycete secondary metabolism. In Regulation of Secondary Metabolism in Actinomycetes, pp. 135-211. Edited by S. Shapiro. Boca Raton, FL: CRC Press.

Virolle, M. J. \& Bibb, M. J. (1988). Cloning, characterization and regulation of an $\alpha$-amylase gene from Streptomyces limosus. Mol Microbiol 2, 197-208.

Received 30 October 1995; revised 31 January 1996; accepted 4 March 1996. 